\title{
DARI KERAJINAN AMAI SETIA KE SOENTING MELAYOE STRATEGI ROHANA KUDDUS DALAM MELAWAN KETERTINDASAN PEREMPUAN DI MINANGKABAU
}

\author{
Susi Ratna Sari \\ Institut Agama Islam Negeri Bukittinggi, Indonesia \\ E-mail: ratnaghucie66@yahoo.co.id
}

\begin{abstract}
Accross the periods of time, women did not pass the live without any obstacles, both the social and the cultural constructions they become isolated, weaken and do not get simmilar turns as well man can have for realizing their existance. This kind of condition laid some women social movements or organizations that aimed at fighting for their freedom and right. On of the movement is Rohana Kuddus (Rohana Kuddus, one of its efforts is building the school fo female student. Another effort if creating the newspaper which was concerned with woman issues as the condition do not give woman the ballaced changes to take a parts in all live aspects. As this movement built the function tent be improved, becoming an enterprenuer office. As the result nowdays it become a well known one. This movement facilitate both educational and economical supports that make them find them self independent while the movement through newspapers Rohana Kuddus has established BC, where the newspaper was the only female newspaper became the first in Indonesia that serves as an educator, controler and critics to the society in related with woman malltreatment. Rohana Kuddus movement made of this; it can contribute in the welfare of women so that woman will be avoided from the violence.
\end{abstract}

Keywords: Kerajinan Amai Setia, Soenting Melayoe, Rohana Kuddus, woman harrashment.

\section{A. Pendahuluan}

Rohana Kuddus seorang perempuan Minangkabau lahir tanggal 20 Desember 1884 di Koto Gadang, dekat Nagarai Sianok, Bukittinggi, Sumatera Barat, beralam nan indah dan berhawa sejuk. Dari Koto Gadang terlihat menjulang Gunung Singgalang dan Marapi 
yang menawan, seperti Bung Hatta ceritakan tentang keindahan dua gunung ini di dalam memoarnya Hatta (1978). Di Koto Gadang yang penuh keindahan itu pula lahir tokoh-tokoh nasional yang dikenang sampai sekarang, seperti Sutan Syahrir adik dari Rohan Kuddus dan Agus Salim sangat toleran dan pejuang nasional sejati. Di samping itu, Koto Gadang juga terkenal dengan negeri yang memiliki yayasan pendidikan pertama di Minangkabau bernama Studiefonds Koto Gadang yang memberikan beasiswa kepada putra putri Koto Gadang untuk melanjutkan sekolah.

Namun, sekolah pada zaman itu bagi perempuan sesuatu hal yang langka. Stigma masyarakat tentang perempuan masih saja sebagai pekerja domestik yang tidak perlu diberdayakan melalui pendidikan. Cara pandang ini terkonstruksi di tengah-tengah masyarakat, sehingga perempuan tetap berada dalam kegelapan sedangkan laki-laki berada alam terdidik yang terang benderang. Akhirnya Rohana Kuddus kecil pun sampai akhir hayatnya tidak pernah mendapatkan sekolah formal seperti laki-laki pada masa itu.

Walaupun demikian Rohana Kuddus kecil bukanlah seorang yang nyaman dengan kondisinya yang termarjinal itu. Rohana Kuddus tipikal perempuan pemberontak terhadap kondisi-kondisi kontruksi ketidakadilan yang tidak manusiawi, sehingga ia harus berjuang keras dengan otodidak. Masa kecilnya yang berdiaspora dari wilayah satu ke wilayah lain memberikan kontribusi terhadap karakteristik jiwanya menjadi seorang pialang dan berorientasi ke depan. Masa kecilnya dihabiskan di sebuah kampung kecil di Alahan Panjang, Kabupaten Solok bersama orang tua angkatnya yang bekerja sebagai jaksa di wilayah itu.

Mengisi hari-harinya di kampung yang berhawa sejuk itu, Rohana Kuddus gigih minta diajarkan membaca kepada isteri sang jaksa. Akhirnya Rohana Kuddus bisa membaca dan sejak itu ia menjadi kutu buku. Menginjak usia delapan tahun, Rohana Kuddus pindah mengikuti ayahnya ke Talu sebuah wilayah di Kapubaten Pasaman Barat. Di sini minat baca Rohana Kuddus mendapat 
perhatian dari orang tuanya, sehingga Rohana Kuddus diberi langganan sebuah surat kabar terbitan Medan bernama "Berita Kecil". Melihat lingkungan anak-anak seusianya tidak bisa membaca, Rohana Kuddus mengumpulkan mereka di serambi rumahnya dan mengajarkan membaca. Jadilah Rohana Kuddus di usia delapan tahun itu sebagai seorang guru kecil yang sangat disenangi teman-temannya. Kegiatan ini dilakukannya setiap pagi di serambi rumahnya.

Pada usia 17 tahun Rohana Kuddus pindah kembali ke tanah kelahirannya Koto Gadang, tinggal bersama neneknya. Ketika itu tidak banyak yang berubah pada perempuan di Koto Gadang, mereka masih saja dalam kegelapan dan termarjinalkan, sehingga rawan mengalami kekerasan, baik seksual, ekonomi, fisik maupun psikis. Untuk melawan kondisi yang demikian itu, Rohana Kuddus bergerak melawannya dengan mendirikan Kerajinan Amai Setia (KAS) dan surat kabar perempuan Soenting Melayoe (SM).

\section{B. Metode Penelitian}

Kerjinan Amai Setia dan Soenting Melayoe, adalah produk perempuan untuk kepentingan kesejahteraan kaumnya yang ketika itu rentan dalam berbagai kekerasan, karena berada dalam kondisi yang dimarjinalkan dan tidak terbedayakan. Penelitian ini dilakukan untuk melihat eksistensi dan sepak terjang Rohana Kuddus dengan Kerajinan Amai Setia dan Soenting Melayoe ini serta implikasinya terhadap kesejahteraan perempuan. Dengan pendekatan historis data dikumpulkan melalui dokumen dan artefak sejarah terkait yang masih utuh sampai sekarang. Data-data ini dianalisis sesuai dengan kaedah Miles dan Huberman (2009), dengan menekankan pada tiga tahap analisis, yaitu tahap reduksi (reduction), penyajian (display) dan kesimpulan (conculusion). 


\section{Temuan Penelitian dan Pembahasan}

Menurut Rohana Kuddus kekerasan terhadap perempuan harus dilawan melalui dua kekuatan, yaitu: Pertama, melalui pendidikan mencerdaskan pola pikir dan ekonomi perempuan; dan Kedua, melalui media yang menyebar luas ke seluruh penjuru. Oleh sebab itu, Rohana Kuddus berupaya kuat agar perempuan mendapatkan pendidikan yang setara dengan laki-laki, sehingga dengan pendidikan itu perempuan mandiri dan memiliki orientasi intelektual yang bisa membangun masa depan perempuan yang lebih baik. Untuk itu Rohana Kuddus mendirikan Kerajinan Amai Setia yang kemudian berkembang menjadi lembaga pendidikan ekonomi bagi perempuan Minangkabau.

Sedangkan media menjadi alat negosiasi kultural dan pemikiran supaya masyarakat tidak lagi mengkonstruksi perempuan sebagai kelas termarjinal yang rawan dengan kekerasan. Sebagaimana disebutkan Hamka bahwa perempuan Minangkabau itu rawan dari kekerasan karena adanya konstruksi budaya dimana elite-elite adat dan agama dengan mudah mempergunakan hak istimewanya untuk dapat memiliki isteri dengan gonta ganti melalui perceraian, kawin paksa dan kawin muda. Kondisi perempuan seperti ini kemudian oleh Hadler (2008) diulas dengan bahasa patriaki belantara nasfsu laki-laki di Minangkabau, dengan dampaknya perempuan mudah dimadu, dicerai dan ditinggalkan begitu saja untuk kepentingan naluriah lakilaki. Poligami menjadi trend, bahkan sangat menyedihkan ketika perceraian dengan mudah dilakukan untuk mendapatkan perempuan lain, sehingga tidak heran seorang laki-laki di Minangkabau ketika itu tidak mengenal anak-anaknya, karena setiap kali perceraian anakanak ditinggal bersama isterinya. Ini gambaran bahwa perempuan mengalami kerawanan kekerasan, baik ekonomi, psikis, fisik bahkan juga kekerasan seksual.

Rohana Kuddus melawan realitas itu dengan pendekatan pendidikan dan pendekatan media jurnalistik perempuan. Pendidikan dengan mendirikan Kerajinan Amai Setia dan media jurnalistik dengan mendirikan Soenting Melayoe. Di sinilah unggulnya Rohana Kuddus, 
di samping memberdayakan perempuan melalui pendidikan, ia juga memberdayakan semua kalangan melalui Soenting Melayoe yang menyebarkan pengetahuan tentang kesejahteraan perempuan kepada masyarakat luas, sehingga kehadiran Soenting Melayuoe bisa disebut sebagai alat kontrol, kritik sosial dan edukasi kesetaraan perempuan pada masa itu.

\section{Kerajinan Amai Setia Lembaga Pendidikan Melawan Marjinalitas Perempuan}

Kerajinan Amai Setia semula sebagai tempat berkumpul bagi perempuan di Koto Gadang lintas usia yang didirikan Rohana Kuddus pada tanggal 11 Februari 1911. Kerajinan Amai Setia berdiri atas keprihatinan Rohana Kuddus terhadap kondisi perempuan di tengahtengah konstruksi budaya dalam memperlakukan perempuan dan lakilaki dalam bidang pendidikan. Perempuan tidak mendapatkan pendidikan sedangkan laki-laki mendapatkannya secara cukup dan tinggi, sehingga akhirnya perempuan menjadi kelas tertinggal dan dari segi intelektual berada dalam ruang intelektual yang hampa. Kondisi ini pula yang menjadikan perempuan mudah mengalami kekerasan yang bisa dilihat dari tingginya angka perceraian, kawin muda, kawin paksa dan seterusnya.

Untuk mengatasi kondisi yang demikian Rohana Kuddus memilih untuk memberdayakan perempuan yang jauh tertinggal ini dengan pendekatan pendidikan. Dalam perspektif Rohana Kuddus ketidakadilan pendidikan yang dikonstruksi masyarakat itu telah menyebabkan perempuan tertinggal, sehingga perempuan pasrah dalam berbagai tindakan kekerasan yang dialaminya. Oleh sebab itu Kerajinan Amai Setia menjadi lembaga pendidikan perempuan di Koto Gadang, dimana Rohana Kuddus menjadi guru yang mengajarkan perempuan menulis membaca dan berhitung. Setelah Kerajinan Amai Setia menjadi pusat pendidikan bagi perempuan Rohana Kuddus menambah mata pelajarannya dengan pendidikan akhlak, pendidikan 
rumah tangga, dan keterampilan untuk perempuan. Kerajinan Amai Setia ini kemudian menjadi model pendidikan perempuan yang diakui oleh Belanda yang bisa diterima oleh perempuan lintas umur baik yang belum maupun yang sudah menikah.

Di samping menjadi lembaga pendidikan, Kerajinan Amai Setia juga menjadi pusat entrepreneur perempuan pertama di Minangkabau, karena setelah belajar membaca dan menulis serta teori keperempuanan, juga diajarkan berbagai keterampilan untuk perempuan. Pelajaran keterampilan ini menjadikan Kerajinan Amai Setia sebagai multi fungsi, sebagai lembaga pendidikan, tempat organisasi perempuan dan sekaligus sebagai tempat unit usaha bagi perempuan menjual hasil-hasil Kerajinan yang dihasilkan perempuan ketika itu. Akhirnya Koto Gadang sampai sekarang terkenal sebagai kampung perajin tangan dan industri rumah tangga sebagai industri kecil dan menengah, seperti terlihat dari laporan Sumiarti, E., \& Suryani, Y. ( 2016) serta Ranelis, R., \& Washinton, R. (2015). Hal ini menunjukkan adanya rantai sejarah yang tidak terputus dalam pergerakan perempuan di Koto Gadang.

Sebagai pemicu entrepreneur perempuan, kehadiran Kerajinan Amai Setia telah berhasil menumbuh kembangkan perempuanperempuan pebisnis yang mandiri dari segi ekonomi, sehingga kemandirian ini dapat mensejahterakan perempuan sebagai salah satu media yang bisa dihandalkan untuk mengatasi kekekerasan terhadap perempuan. Perempuan-perempuan yang berada dalam tingkat kesejahteraan yang rendah seperti berada dalam kemiskinan, diprediksikan perempuan rawan terhadap kekerasan. Hal ini bisa dilihat dari kasus-kasus tingginya angka perceraian dan kekerasan, yang salah satunya disebabkan oleh faktor ekonomi. Melalui data perceraian yang direkap pertahunnya oleh Makamah Syariah/ Pengadilan Agama antara tahun 2005-2009, tampak bahwa faktor ekonomi menjadi salah satu pemicu yang tidak pernah absen sebagai penyebab terjadinya perceraian itu. Misalnya pada tahun 2005 ditemukan dari 138.891 jumlah perceraian di Indonesia, 24.251 kasus 
diakibatkan faktor ekonomi. Begitu juga tahun 2006 dari 138.909 perceraian dimana 24.556 kasus akibat dari ekonomi. Tahun 2007 dari 145.554 kasus perceraian 26.519 kasus disebabkan oleh ekonomi, begitu juga di tahun 2008 dari 175.705 kasus perceraian dimana 35.526 kasus diakibatkan oleh ekonomi dan tahun 2009 dari 201.072 kasus perceraian dimana 43.309 kasus diakibatkan oleh perekonomian, Silfia Hanani (2013).

Hamka menyebutkan, faktor kemiskinan juga bisa menyebabkan perempuan mudah mengalami kekerasan, sebagaimana dideskripsikan oleh Hamka dalam pantun yang dikutip kembali oleh Hadler (2008) Teloek Bajoer laboehan kapal/ Belanda moedik bersekoetji/ Boenga lajoer keboenlah tinggal/ Tiadalah koembang kembali lagi. Artinya, perempuan mempunyai kedudukan yang lemah, mudah dicerai dan mengalami kekerasan akibat dari kemiskinan atau ekonomi. Posisi perempuan tidak ditempatkan dalam kesetaraan dan berkeadilan tetapi berada dalam kelompok yang dimarjinalkan, kemudian rawan menjadi objek kekerasan. Persamaan hak antara lakilaki dan perempuan serta penghapusan diskriminasi terhadap perempuan sampai saat ini masih menjadi permasalahan dalam masyarakat dan terus diperjuangkan aktivis perempuan, (Nurhasanah, 2012). Salah satu aktivis perempuan yang memperjuangkan hak-hak perempuan tersebut adalah Rohana Kuddus.

Kerajinan Amai Setia yang didirikan Rohana Kuddus salah satu tujuannya adalah untuk memberdayakan ekonomi perempuan, karena hasil dari Kerajinan dan usaha-usaha ekonomis yang dilakukan perempuan di Kerajinan Amai Setia keuntungannya dibagikan kepada perempuan-perempuan, bahkan dengan perkembangan Kerajinan Amai Setia sebagai sentra ekonomi perempuan maka Kerajinan Amai Setia menjadi daya tarik bagi perempuan untuk bergabung sehingga Kerajinan Amai Setia ketika itu tidak hanya menjadi pusat Kerajinan bagi perempuan tetapi tumbuh dan berkembang menjadi unit usaha semacam koperasi. Kerajinan Amai Setia juga bisa disebut sebagai koperasi perempuan pertama di Minangkabau yang bergerak dalam 
usaha Kerajinan perempuan. Tidak ada yang menandingi unit usaha perempuan di Kerajinan Amai Setia ketika itu, sehingga Kerajinan Amai Setia benar-benar menjadi model pengembangan ekonomi perempuan yang membanggakan ketika itu, Tamar (1980).

Keberadaan Kerajinan Amai Setia yang dibangun oleh Rohana Kuddus sebagai kontestasi perempuan dari diskriminasi, perlawanan ini dibangun melalui etos kerja ekonomi perempuan, karena Rohana Kuddus sadar betul dorongan etos kerja yang terpasung di kalangan perempuan ketika itu karena budaya yang tidak berpihak terhadap kesejahteraan perempuan. Pendapat Rohana Kuddus ini sejalan dengan Weber (2009) bahwa etos kerja itu sebuah kekuatan yang mendorong seseorang untuk membangun kesejahteraanya dengan tindakan rasional. Etos kerja juga mengeluarkan seseorang atau kelompok orang untuk memiliki orientasi masa depan yang berkesejhateraan Imron, Sumantadinata, \& Soewardi (1999). Kerajinan Amai Setia yang dibangun oleh Rohana Kuddus, mempunyai tujuan yang demikian, sehingga perempuan-perempuan bisa bangkit menjadi komunitas yang bertradisi innovation personality bukan menjadi komunitas authoritarian personality yang tunduk dengan keadaan.

Rohana Kuddus sadar betul jika perempuan tidak memiliki orientasi tentu perempuan akan selalu menjadi masyarakat termarjinal. Salah satu masyarakat marjinal itu menurut Budiman (2000) adalah masyarakat yang tidak memiliki need for achievement, tidak memiliki semangat untuk berprestasi dan tidak memiliki etos kerja, sehingga perempuan akan tetap dalam kondisi tanpa mempunyai growth philospy, menyerah dengan keadaan serta tidak kreatif. Dalam konteks ini Rohana Kuddus dengan Kerajinan Amai Setia-nya telah membuktikan ungkapan Myrdal \& Other, (1968) terjadinya kemiskinan tidak disebabkan oleh terbatasnya sumber daya alam, tetapi lebih dominan disebabkan oleh rendahnya etos kerja dan rendahnya kualitas sumber daya manusia. Oleh sebab itu masyarakat perlu mendapatkan motivasi supaya memiliki etos kerja tersebut, 
sehingga lahir kelompok-kelompok yang memiliki need for achievement atau mempunyai tradisi innovation personality bukan memiliki budaya soft culture. Maslow, Frager, Fadiman, McReynolds \& Cox (1970) juga telah meyakinkan bahwa dalam menggerakkan etos kerja itu ada gerakan motivasi yang diberikan pada masyarakat, sehingga masyarakat mempunyai daya saing dan mampu menciptakan kedinamisan dalam membangun ekonominya. Keberdaaan Rohana Kuddus di Kerajinan Amai Setia membangun etos kerja perempuan itu sehingga perempuan mempunyai orientasi kedepan untuk membangun kesejahteraan. Orientasi yang dibangun Rohana Kuddus itu pada dasarnya menjadikan perempuan bisa perlahan-lahan mendekontruksi perspektif tentang perempuan, sehingga perempuan tidak lagi termarjinalkan. Dengan kondisi yang tidak termarjinalkan itu, jelas memberikan konstribusi positif kepada kesejahteraan perempuan dan perempuan tidak lagi berada dalam kerawanan kekerasan.

\section{Soenting Melayoe Bukti Keintelektualan Melawan Otoritas}

Rohana Kuddus dalam memajukan perempuan tidak hanya melalui Kerajinan Amai Setia saja, tetapi juga mendirikan Soenting Melayoe. Sebagai surat kabar perempuan, yang bertujuan untuk melawan ketidakadilan terhadap perempuan dengan edukasi yang lebih luas kepada khlayak masyarakat. Di tangan Rohana Kuddus lahir Soenting Melayoe (SM), surat kabar perempuan pertama di Indonesia. Surat kabar ini terbit pertama kali tanggal 10 Juli 1912 di Padang dan beredar luas ke seluruh daerah terutama di wilayah Sumatera Barat yang waktu itu lebih dikenal dengan Sumatera Tengah, Hanani (2011).

Soenting Melayoe dipenuhi tulisan-tulisan yang berkaitan dengan perempuan, dimana sebelumnya perempuan tidak pernah mendapat liputan dan ulasan dari surat kabar yang ada, sehingga surat kabar betul-betul menjadi wilayah maskulinitas. Kondisi yang demikian menurut Rohana Kuddus telah memperpanjang kehidupan 
perempuan dalam kondisi yang dimarjinalkan. Soenting Melayoe melawan otoritas melalui tulisan-tulisan edukasi berkeadilan gender. Di antara tulisan Rohana Kuddus di Soenting Melayoe yang terkait dengan edukasi berkeadilan gender itu dapat dilihat dari tulisan berjudul Setia Gerakan Perempuan Zaman Ini (SM 23 Mei 1913), Perhiasan Pakaian (SM 7 Agustus 1912), Perempuan (SM 15 Desember 1918), Mencari Isteri (19 Desember 1920) dan seterusnya.

Kehadiran Soenting Melayoe menjadi fenomenal sehingga tidak sedikit yang menuding Soenting Melayoe sebagai surat kabar penentang arus. Karena Rohana Kuddus dengan tulisan-tulisannya menentang otoritas laki- laki yang tidak berpihak pada kesejahteraan perempuan. Bahkan tulisan-tulisan kritikan otoritas laki-laki itu dilanjutkan oleh Hamka, sebagaimana dapat dilihat dari tulisantulisannya dalam buku Merantau ke Deli. Jauh sebelum Hamka mengkritik tentang prilaku elite-elite itu, Rohana Kuddus telah melakukannya seperti dipertegas oleh Hadler (2008) dimana kehadiran Soenting Melayoe yang dinahkodai Rohana Kuddus dapat menjadi alat pengawas otoritas laki-laki terhadap perempuan di Minangkabau ketika itu. Otoritas yang dimaksudkan oleh Hadler adalah kontruksi hak istimewa elite-elite baik agama dan adat dalam bertindak tanpa memikirkan kesejahteraan perempuan, sehingga perempuan rawan mengalami perceraian dan kekerasan.

Untuk keluar dari kondisi otoritas-otoritas yang tidak berpihak pada kesejahteraan perempuan itu, Rohana Kuddus berjuang melalui Soenting Melayoe dengan memberikan pendidikan kepada masyarakat luas tentang kesejahteraan perempuan, sehingga gerakan-gerakan untuk membebaskan perempuan setelah Rohana Kuddus berkembang dan semakin dimengerti oleh masyarakat, sehingga lahir gerakan terhadap pembebasan perempuan ini tidak saja dipelopori oleh perempuan bahkan juga oleh laki-laki.

Setelah pergerakan Rohana Kuddus, di kalangan ulama laki-laki terkenal di antaranya pergerakan pemberdayaan perempuan yang dilakukan Syeikh Abdullatif Syakur (1882-1963) yang mendirikan 
Madrasah Perempuan dan diikuti dengan mendirikan Majalah Perempuan pertama di Minangkabau yang bernama "Djauharah Oentuk Bangsa Perempoean” terbit secara berkala di Balai Gurah Kabupaten Agam tidak jauh dari Koto Gadang tempat pergerakan Rohana Kuddus, sehingga Syeikh ini bisa pula dijuluki ulama feminis di Minangkabau yang sangat peduli terhadap kesetaraan dan kesejahteraan perempuan. Bahkan Syeikh Abdullatif Syakur juga membuat analisis sosial termasuk tentang perempuan melalui tafsir sosial yang dibukukannya dengan judul Addakwah wal Irsyad ila Sabilir Rasyad diterbitkan pada tahun 1940 oleh penerbit Tsamratul Ikhwan sebuah penerbit ternama di Bukittinggi.

Kemudian bermunculan pula setelah itu pergerakan-pergerakan dan perkumpulan perempaun sebagai bentuk kesadaran perempuan terhadap hak dan kewajibannya, misalnya lahir organisasi Serikat Kaoem Iboe Soematera (SKIS) pada tahun1924. Tanggal 17 Agustus 1929 Serikat Kaoem Iboe Soematera melaksanakan kongres pertama, dalam kongres ini disepakati perubahan nama Jurnal Asjraq yang diterbitkan Serikat Kaoem Iboe Soematera menjadi jurnal yang bernama Soeara Kaoem Iboe Soematera yang berisi tentang perjuangan perempuan, bahkan isinya dominan dalam bentuk catatancatatan perempuan Soematera.

Pada pembukaan kongres pertama Serikat Kaoem Iboe Soematera di Gedung Bioskop Scala Bukittinggi dihadiri oleh 800 laki-laki, kemudian beberapa orang perempuan menyampaikan makalah dengan berbagai tema. Di antara perempuan yang menyampaikan makalah adalah Seri Kiam Azizi, Noerani, L. Kahar Masjhur, Noermi dan R Sitti Noer Malliah Zainuddin, semuanya berbicara tentang perempuan dan perjuangan serta pergerakannya dengan pendekatan berbagai perspektif Hadler, (2008). Dengan adanya perempuan-perempuan menyampaikan gagasan dan pokok pikirannya di dalam kongres yang dihadiri oleh lebih kurang 800 lakilaki itu terbukti ada implikasi yang signifikan dari pergerakan- 
pergerakan perempuan yang telah dilakukan oleh pendahulunya seperti yang dirintis oleh Rohana Kuddus.

Keberhasilan Rohana Kuddus bergerak melalui Soenting Melayoe, tentu bisa pula disebut bahwa Soenting Melayoe menjadi media aksi affirmatif yang menggerakkan perempuan supaya terlibat di ranah publik termasuk dalam berpolitik, seperti lahirnya organisasi-organisasi perempuan Serikat Kaoem Iboe Soematera setelah Rohana Kuddus. Aksi affirmatif ini pun sekarang disadari kembali keberadaannya, setidaknya dapat dilihat dari kebijakan 30\% pengurus partai politik adalah perempuan, seperti diatur dalam Pasal 65 Ayat 1 UU No 12/2003, serta kebijakan keterwakilan perempuan di parlemen dengan kuota 30\%. Kebijakan ini dibutuhkan mengingat rendahnya keterlibatan perempuan di ranah politik. Indonesia baru mempunyai angka keterwakilan perempuan di parlemen 18,03\%, sementara Kamboja dan Filipina sudah mencapai 20\%, sedangkan Timur Leste $30 \%$. Sampai saat ini sudah ada negara di dunia yang memiliki keterwakilan perempuan di parlemen di atas 30\%, diantaranya adalah Rwanda dengan angka keterwakilannya 56,3\% kemudian disusul posisi kedua Andora (53,6\%), posisi ketiga Swedia (45\%) dan Indonesia merupakan negara urutan ke-64 Budiarti (2011).

Rohana Kuddus dengan pergerakan Soenting Melayoe telah memberikan kontribusi yang begitu besar untuk mensejahterakan dan mendorong kemajuan perempuan. Untuk menghargai jasa-jasa Rohana Kuddus ini pemerintah telah memberikan penghargaan terhadap Rohana Kuddus dengan dinobatkan Rohan Kuddus sebagai wartawati pertama di Indonesia. Penghargaan ini diberikan pada Hari Pers Nasional ke-3 pada 9 Februari 1987 yakni setelah enam tahun Rohana Kuddus meninggal di Jakarta tanggal 17 Agustus 1972.

\section{Penutup}

Rohana Kuddus merupakan perempuan pejuang yang bergerak melalui pendidikan dan jurnalis persurat kabaran wanita. Kerajinan 
Amai Setia merupakan lembaga pendidikan bagi perempuan yang kemudian berkembang menjadi lembaga entrepreneur perempuan, sehingga perempuan memiliki kualitas sumber daya manusia dan kemandirian ekonomi, sehingga dengan gerakan itu perempuan tidak lagi termarjinalkan oleh otoritas laki-laki atau oleh konstruksi budaya yang tidak memiliki keadilan gender.

Roha Kuddus juga mendirikan Soenting Melayoe sebagai media jurnalis perempuan pertama di negeri ini yang bertujuan untuk mengontrol, mengkritik dan mendidik masyarakat untuk berkeadilan gender. Dimana sebelumnya, perempuan dan kajian-kajian tentang perempuan tidak pernah terpublikasi atau ditulis oleh surat kabar, karena surat kabar ketika itu simbol dari maskulin. Dalam pandangan Rohana Kuddus surat kabar juga harus memberikan perhatian untuk perempuan, oleh sebab itu Rohana Kuddus bertekat melahirkan sebuah surat kabar perempuan, untuk menandingi otoritas surat kabar yang tidak memberikan ruang pada perempuan.

Pergerakan-pergerakan keperempuanan yang dilakukan oleh Rohana Kuddus ternyata mempunyai konstribusi terhadap kesejahteraan perempuan, diantaranya perempuan dapat mandiri dan memiliki intelektualitas sehingga perempuan tidak lagi menjadi objek kekerasan, baik seksual, psikal, fisik dan ekonomi. Di samping itu yang terpenting lagi adalah, usaha-usaha yang dilakukan Rohana Kuddus telah mendorong lahirnya gerakan-gerakan pembebeasan perempuan baik yang dipelopori oleh perempuan itu sendiri maupun oleh laki-laki. Gerakan-gerakan itu telah berkonstribusi dalam mengeluarkan perempuan dari ketidakadilan dari berbagai aspek, baik dari aspek pendidikan, ekonomi, politik, budaya dan seterusnya. 
Dari Kerajinan Amai Setia Ke Soenting Melayoe Strategi Rohana Kuddus dalam Melawan Ketertindasan Perempuan di Minangkabau

\section{Referensi}

budiarti. (2011). Bayang-bayang afirmasi keterwakilan perempuan di parlemen Indonesia.

Budiman, A. (2000). Teori pembangunan dunia ketiga. Jakarta: Gramedia Pustaka Utama.

Hadler, Jeffrey.2008. Sengketa tiada putus matriarkat, reformasi agama dan kolonialisme di Minangkabau. Freedom Institute. Jakarta.

Hadler, J. (2008). Muslims and matriarchs: Cultural resilience in Indonesia through Jihad and colonialism. Cornell University Press.

Hanani, S. (2011). Rohana Kudus dan pendidikan perempuan. Marwah: Jurnal Perempuan, Agama dan Gender, 10(1), 3747.

Hanani, S. (2013). Rafika Media. "panggung sandiwara perselingkuhan. Yogyakarta: Rifka Annisa.

Huberman, A. M., \& Miles Mattew, B. (2009). Manajemen data dan metode analisis. Dalam Norman K. Denzin Dan Yvonna S. Lincoln, Handbook of Qualitative Research, Terjemahan, Yogyakarta: Pustaka Pelajar.

Imron, K. S., Sumantadinata, K., \& Soewardi, K. (1999). Genetic variation in cultured stocks of Tiger Shrimp (Penaeus monodon) in Indonesia. Indonesian Fisheries Research Journal, 1, 10-18.

Jaya, Tamar. 1980. Rohana Kuddus riwayat hidup dan perjuangannya. Jakarta. Mutiara

Maslow, A. H., Frager, R., Fadiman, J., Mc Reynolds, C., \& Cox, R. (1970). Motivation and personality (Vol. 2). Harper \& Row New York.

Mohammad Hatta. (1978). Memoir. Jakarta: Timtamas. 
Myrdal, G., \& Others. (1968). Asian drama, an inquiry into the poverty of nations.

Nurhasanah, N. (2012). Penghapusan diskriminasi terhadap perempuan dalam bidang perkawinan menurut ham dan hukum perkawinan Islam di Indonesia. Kafaah: Journal of Gender Studies, 2(1), 103-122.

Ranelis, R., \& Washinton, R. (2015). Kerajinan rendo bangku Koto Gadang Sumatera Barat. Ekspresi Seni, 17(2).

Sumiarti, E., \& Suryani, Y. (2016). Gambaran Industri Kecil dan Menengah (IKM) kerajinan perak Koto Gadang sebagai salah satu kerajinan unggulan Sumatera Barat. Poli Bisnis, 7(2), 7687.

Weber, M. (2009). The theory of social and economic organization. Simon and Schuster. 
Dari Kerajinan Amai Setia Ke Soenting Melayoe Strategi Rohana Kuddus dalam Melawan Ketertindasan Perempuan di Minangkabau 